Revista Iberoamericana, Vol. LXXI, Núm. 210, Enero-Marzo 2005, 241-259

PERGAMINHOS DO FEMININO

\author{
POR \\ MARÍA LÚCIA DAL FARRA \\ Universidade Federal de Sergipe
}

A Alba Abreu

Manuscritos de Felipa, novela da escritora brasileira Adélia Prado, publicada em 1999, ostenta a feição de um diário íntimo, cujos registros ocorrem um tanto ao sabor da temperatura emocional em que são capturados os eventos triviais do cotidiano de uma mulher que vive numa pequena cidade do interior de Minas Gerais. ${ }^{1}$ Esta Felipa (nome, cuja etimologia indicia duplicidade), mãe de família e avó, criatura temente a Deus enceta seus escritos porque deve encarar, agora, um enfrentamento difícil com a dor que lhe voltou. Mas esse sofrimento, ante-câmera do tenebroso e do oculto contido na suspeita de uma grave enfermidade ou do envelhecimento que, afinal, lhe chegou, introduz antecipadamente Felipa num limiar: o da morte. Daí que o esforço da escrita, maneira de exercer algum domínio sobre sua vida, seja o de um assentamento verbal de especulações que, partindo do nível absolutamente corriqueiro da existência de Felipa, possam endereçá-la à transcendência e ao esboço de algumas respostas que lhe facultem um urgente entendimento acerca do seu estar-no-mundo. É, portanto, da perspectiva específica da condição feminina, que dimensiona sua relação com os outros (marido, filhos, netos, irmãs, amigos, beleza, arte, realidade brasileira e mundial, etc) e com o sagrado, que Felipa traz à cena tais questionamentos desenvolvidos em 40 fragmentos -número bíblico da provação.Ora, esse lugar cultural e psicológico, espaço de gênero de onde Felipa escreve, vai se revelando, diante da ameaça da velhice e da morte, como sendo o espaço primitivo e ancestral da mulher bíblica. ${ }^{2}$ É, portanto, da perspectiva do protótipo feminino da culpa e do remorso, da mulher que é tentada e peca, da que se acha em estado de falta, da que deve aprender as qualidades da paciência e da modéstia, da resignação e da privação, enfim, do “fiat Maria”, que Felipa precisa “falar, falar até entender, até ser perdoada, até ser transformada” (46). Contribuem, para tal, também o processo onírico por que passa, de maneira que sua escrita revela tanto um corpo magoado, uma fala em gritos, quanto um “orar em línguas”, um dialeto desconhecido. Seria possível dizer que seus manuscritos

\footnotetext{
${ }^{1}$ Utilizo a edição da Sciliano, cujas citações serão identificadas pelas páginas entre parênteses que se lhe seguem.

${ }^{2}$ Remeto o leitor à obra de Jean-Marie Aubert, intitulada La femme. Antiféminisme et Christianisme.
} 
encerram uma espécie de “imitação de Cristo” emitida por uma sensualidade dolorosa (semelhante à de Teresa D’Ávila), à maneira de um Jó.

De qualquer modo, trata-se de uma confissão (consciente ou inconsciente), de uma tentativa de exorcização do "continente sombrio", daquilo que se refere à esfera cultural do feminino: o imaginário, o noturno, o desconhecido, o desenfreado, a desordem. ${ }^{3} \mathrm{E}$, neste caso, aquele que atua como receptor privilegiado desse ato confessional (onde se enfrenta o próprio “demônio” da tentação, da tristeza, do medo, da desdita, da preguiça, da depressão) é (sem contar com o leitor virtual, nem com o sacerdote, médico ou psicanalista -figuras ritualísticas que Felipa vai pouco a pouco descartando da sua narrativa)- o próprio Deus.

Felipa busca, assim, não apenas uma sabedoria que a ultrapasse (e que a torne arauto d’Ele), mas, sobretudo, uma redenção enquanto mulher: seu desejo de parúsia se transubstancia no desejo de ser parida outra vez: "Deus há de vir com entranhada misericórdia e me parir de novo, onde a primeira vez me pariu, (...) no paraíso” (105). A metáfora dos “neutrinos” (141), utilizada pela narradora (a das partículas que se transformam em outras à medida em que se deslocam) dá a medida da metamorfose que vai se operando nos manuscritos, como também da simbiose (dialética) entre vida desperta e onírica desta pecadora que almeja, afinal, oferecer o peito à criança divina.

О “ВІсно”

Os quarenta capítulos que perfazem a narrativa e congregam os sobressaltos de Felipa, tanto diante das miúdas quanto das brutas surpresas que a vida lhe reserva, transcorrem durante aproximadamente um ano, passando pelo Natal, pela quaresma, pela Páscoa, pelo alegre e rejuvenescedor maio, pelo junho festivo de Santo António. ${ }^{4}$ Esta quarentena por dentro da escrita, exercício de especulação verbal acerca das vicissitudes do feminino, que encerra uma espera, uma provação e um amadurecimento, vai favorecer o transcorrer de um ciclo para o alcance de uma mudança radical, que instituirá, como se verá, a transmutação de uma para outra ordem de ação e de vida. ${ }^{5}$ É assim que, ao longo desse tempo, a contínua oscilação da saúde física e psíquica de Felipa vai cumprir um

\footnotetext{
${ }^{3}$ Estas especulações acerca do feminino enquanto "continente sombrio" provêm do estudo de Monique Schneider -De l'éxorcisme à la psychanalyse. Le féminin expurgé.

${ }^{4}$ Há, no capítulo II, à página 11, uma referência inicial à Santa Terezinha que, graças à indicação de idade da santa (24 anos), a confirma como Santa Terezinha do Menino Jesus. O tempo de festejo da referida santa é outubro, o que pode fazer supor que a narrativa teria sido encetada mais ou menos a partir desse mês. Como os manuscritos continuam ainda após as referências juninas, é provável que fechem o ciclo de um ano.

${ }^{5}$ A aproximação numérica com o sagrado, sobretudo com a Bíblia, é inevitável: David e Salomão reinam por 40 anos; a aliança com Noel ocorre 40 anos após o dilúvio; Moisés é chamado por Deus aos 40 anos e permanece 40 dias no alto do Sinai; Jesus prega por 40 meses; os hebreus infiéis são condenados a errar por 40 anos no deserto; 40 dias de chuva punem a humanidade pecadora; Jesus é conduzido ao templo 40 dias após seu nascimento, sofre a tentação no deserto por 40 dias, ressuscita depois de 40 horas no interior do sepulcro, etc. Para mais detalhadas aproximações, remeto o leitor ao Dictionnaire des symboles de Jean Chevalier e Alain Gueerbrant.
} 
percurso subterrâneo de fantasmagorias que eclodem em pelo menos nove sonhos registrados, sacudindo-a, a ponto de que providencie, ainda que paulatinamente, substanciosos recursos de cura.

Deste modo, a sua célebre tendência à postergação de decisões terá de ser suplantada, e médicos, terapeutas, ginástica e dietas vão ingressar no seu calendário de compromissos, cruzando com novenas, labutas domésticas, romaria a Aparecida do Norte, privações, dias de folga na praia, invocações permanentes a Deus, ofertas diárias e tácitas de sacrifícios, rezas, vida em família, constantes litígios com o capeta, penitências, culpas e remorsos, passeios empenhados pela joalheria e lojas de comércio, recaídas, jejuns, lembranças, palestra no Centro Cristão de Idosos -tudo amalgamado definitivamente na necessária e obrigatória escrita.

O trabalho de manuscriturar funciona, pois, como uma espécie de homeopatia que vai, palavra por palavra, lhe revelando a "verdade" que, afinal, nada mais é que o cadinho onde se manipula o ungüento contra o seu pior inimigo: o pânico -de modo que ela possa atingir apenas o que pretende, a almejada "normalidade”, ainda que assombrosa. Ser normal, neste contexto, compreende o entendimento da morte como uma passagem, da saúde como uma fé que se ganha quando se pede muito por ela; compreende também a assunção da sabedoria de que o medo e a coragem não passam de ídolos. Em termos de narrativa, a normalidade consiste no encontro de uma simplicidade lingüístico-estilística que registre com vigor essa provação feminina, essa espantosa experiência de envelhecimento sofrida pela mulher.

Felipa tem consciência do "bicho encravado" no seu pescoço, o que lhe impede a manutenção da postura ereta e lhe franquia a constatação de que o seu olhar "só alcança o horizonte com o sacrifício das servicais", fato que, segundo ela, "sendo anatômico é também religioso em sua origem” (124). Esse "bicho”-metáfora da velhice-encarna aqui a doença que acometeu Felipa há quatro anos atrás, e que parece ter sido extirpada. Todavia, sobrevivendo em cicatriz, ela persiste na sua silenciosa e constante insídia de regresso, envergando Felipa, impedindo-a que se endireite, ao mesmo tempo que atesta a subserviência dela diante do sagrado misterioso, sinalizando, à flor da pele, o mapa psicológico de onde lhe mina o medo.

Sendo, como todos da família Marroio, de constituição sentimental afeita à dor, esta “glutona do Córrego da Ferrosa” não escapa do tom redentorista dessa sua raça ocupada em pagar tributos à tristeza. Como ela própria esclarece, tal "lado quaresmal” da sua família diz respeito a "um povo de chorões, bom pra se juntar num vale, fundar sozinhos uma cidade cercada de muros altos, chamada com propriedade Vale de Lágrimas, objeto de visitação para turistas” (33). Talvez seja essa herança ancestral que contribua para que Felipa alcance, agora, o paroxismo da tortura, vivendo num clima repleto de pequenas angústias, de miúdos mas significativos mal-estares, numa atmosfera de iminentes eventos atocaiados que produzem o "onipresente susto" e o "paralisante medo", este que a ronda como "lobo com fome" (123).

Universo a um passo de desintegrar-se, assemelhado àquele de presságios desagregadores, próprio do Antigo Testamento, o tempo de Felipa é, todavia, o do nosso século, o da nossa pós-modernidade, assim erigido não apenas mercê dos acontecimentos provincianos da cidade em que vive e à herança familiar, mas também em virtude de tudo 
aquilo que, se sabe, anda pelo mundo e pelo país, objeto de noticiário por parte da televisão e dos comentários locais.

Todavia, para além de todas essas ameaças que estremecem sua existência, o medo de Felipa nasce propriamente do espanto de estar ainda viva num planeta tão convulso, em que impera e grassa a morte ou, quanto mais não seja, num espaço que transforma profundamente a ela, que a torna outra da que era, a ponto de dificultar cada vez mais o seu auto-reconhecimento. Felipa se encontra, pois, apavorada "de existir num mundo onde a morte existe e corta meu canto no meio, diminui meu hausto, me faz respirar pior, com as costas encurvadas, com medo de levantar os olhos e o céu estrelado não ser mais consolo" (79).

A narrativa é, assim, rasgada por essas "ranhuras" que o "bicho" deixou na sua "nuca, na altura da tirióide” (103), tanto quanto pelo sobressalto causado pela morte ou pela doença de pessoas que lhe são próximas: pela de Angelina, que morreu de câncer, e cuja vida anônima impressiona sobremaneira à Felipa; pela doença de sua irmã Bárbara, a quem o soro deixou marcas de cadeias nos pulsos; pela morte angustiada da amiga Martina, a quem Felipa julga não ter dado suficiente assistência, desenlace por isso mesmo fonte de remorsos e de culpas que a atormentam; pelo truculento estupro e assassinato de Valdemildes, que Deus poderia ter evitado - mas como, se Ele sequer se permitiu fazê-lo ao seu próprio Filho?

Provavelmente é também o "bicho” que, pródigo em investidas, a assalta em sonhos aos quais seria necessário, para iluminá-los, o mesmo espírito que instruiu Daniel. Há, pois, em ordem cronológica, o sonho do naufrágio, o da menina-estuprada, o do apelonão-atendido, o do casamento, o do leite, o dos adoradores, o das duas-mulheres-vestidasiguais, o da velha-criança e o da amamentação. Ora, aquele "subtexto" que, enquanto escritora, Felipa jura abominar, pode ser encontrado justamente no desenrolar desses sonhos que, como contrapontos da narrativa, ao mesmo tempo a confundem e a elucidam, como um riacho que a inundasse, devastando-a, mas fertilizando-a também.

\section{O “vesPeiro”}

Felipa se dá conta, ao longo desses manuscritos, de que tudo concorre para confundila, “as palavras sendo o que há de pior”. E, todavia, é delas que necessita, pois que não the basta contemplar as coisas: ela precisa ouvir o que vê, "ainda que um vocativo, uma vogal alongada até a rouquidão” (80). Na verdade, a fala é muito perigosa, cria confusão, é uma fogueira onde a gente queima as mãos. É um enxu; uma colméia em que habitam vespas prontas a aplicar o ferrão em quem nela bulir.

Foi, aliás, com palavras que o mundo se criou e, segundo Felipa, é por falta delas que o planeta agora fenece: de pura “inanição de palavras” (31). Daí sua cautela: é preciso examiná-las com minúcia, perscrutando a tonalidade que exalam, o efeito que provocam, a sugestão que inspiram -tudo com o intuito de que não a confundam tanto, e que, antes, possam salvá-la, visto que é por meio delas que Felipa empreende a sua quarentena em busca da cura. Afinal, qualquer "língua é Deus falando", razão pela qual a língua "nos escapa tanto" e as palavras só se mostram ao "desfocado olhar da poesia, à sua densa névoa, quando tudo suspende-se ao juízo e apenas cintila, em vapores d’água, orvalho, 
vultos movendo-se em neblina. Você pressente e teme porque a beleza é viva e te olha. Chama pelo nome ao que a procura.”(47)

Um exemplo da sugestão que as palavras provocam é a cisma de Felipa sobre "nervos à derme": segundo conclui, tal expressão endereça a "lençóis de cambraia, leques, saia bufando e escarradeiras de louça” (45). Também outras palavras são submetidas a seu crivo: a palavra "eixo", por exemplo, parece ter apenas "beleza interior, consolo dado a mulheres feias e bondosas, idéia e consolo enganosos, porque beleza radia e o que radia radia para fora" (30). Da mesma forma, a palavra "solidônia" que, segundo ela, é uma "palavra enjoada” (104), precisa urgentemente ter restaurada a sua decência. As palavras também são apreciadas a partir do parentesco sonoro que estabelecem, e daí que a paronomásia explique, por exemplo, a associação entre "noivo" e "goivo", segundo Felipa, uma aproximação funérea embutida no seu sonho de casamento (132).

Quanto à sua maneira de redigir, Felipa diz trabalhar pela “elisão”, pela “supressão”, pela "limpada”. Todavia, sabe que, mesmo assim, sequer é capaz de chegar ao âmago das coisas, visto que não pode passar "sem adjetivos”, atribuição que nos é própria, a nós, míseros mortais: afinal, "ser humano, mais que parecer um porco, é adjetivar” (31). A colocação do adjetivo é, também, motivo de comentários: onde deve ser situado, antes ou depois do substantivo? Algumas vezes, é preciso que Felipa quebre o costume e afirme, por exemplo, que "hemorragia é forte palavra”, disposição inusual de grafar, que chega a nos pejar, e que apenas não faz espécie quando encontrada "nas poesias” (45).

Ao longo de suas declarações, Felipa vai confessar, por exemplo, que escreve "meio errado” e que tem sempre a sensação de que está enganando "as pessoas que me julgam letrada", visto que pega as palavras "no palpite”. Acontece que, mesmo assim, como se certifica, acaba acertando, porque escreve apenas sobre o fundamental, sobre aquilo que nos desespera: ela só fala "do que dói e grito todo mundo entende” (46). Para escrever, Felipa também necessita de "ligaduras”: se espanta, se justifica, pede explicações, muito embora seja quase muda e silenciosa, propensa a jejuns; segundo crê, ajudaria, para se curar da língua que fala, conhecer uma “outra língua” (46).

Como não poderia deixar de ser, esta manuscrituradora é também muito crítica em relação à maneira crassa como é usada a língua portuguesa: abomina a "concordância errada”, que considera “surdez direta”, e a feiúra da “elisão de pronomes e plurais”, o que provoca uma verdadeira "otite” (138). De resto (acaba ela por convir), tudo o que se diz é apenas "um jeito humano de falar”, visto que a língua sequer "alcança a margem do que se sente” (147). Ou seja: a insuficiência da língua enquanto expressão do que se sente ou se conhece ou se imagina ou se observa ou se deseja -é a evidência básica constatada por Felipa: e eis como se explica o "vespeiro".

Todavia, é por isso mesmo que se escreve, para desafiar essa incapacidade, para vergá-la, para nos obrigar a ir mais longe, lá onde a gente encontra apenas um balbucio de êxtase diante daquilo que é sempre impronunciável. A tarefa de Felipa é, pois, a de trabalhar as palavras a fim de que elas se tornem "um dialeto desconhecido, um orar em línguas” (46) -de forma que as palavras sejam restituídas definitivamente ao sagrado, àquilo que é a verdadeira natureza delas.

Ser artista é, portanto, produzir coisas "que as pessoas vejam e digam: meu Deus, como que eu não vi isto!” (74). O artista retém aquilo que sobrou do mundo -“galho de 
roseira no papel de seda, o risco de um bordado”. Por isso, causa admiração “quem desenhou sua rosa igual à que ninguém fez, a rosa mortal e divina, a que veio antes” (42). E Adélia Prado, contestando talvez aquela ala crítica que a julga empenhadamente cristã, acaba declarando, pela pena de Felipa, que artista "é artista e pronto, católico, cego ou bancário vale tanto para a arte como ter dente encavalado, lábio leporino, ou ser bonito de doer" (74).

O artista busca a beleza, e deve ter, como ela própria afirma a seu respeito, espírito de "colecionador-arqueólogo", guardando as coisas que albergam "natureza de nuvem”, aquilo que é valioso, e tão sutil, que se esvai no momento em que se julga capturá-lo. Felipa quer ocupar-se de tudo o que é bonito ("preciosos registros, farelos de ouro, retalho de pano bom”, “jóias de desenho especioso”) para encerrá-lo "numa caixa com chave para abrir de vez em quando e sonhar” (53). A beleza das jóias, sobretudo das antigas (visto que “jóias modernas são horríveis, parecem poesia concreta, obras de hábil artesão”), daquelas “do tipo que os nazistas guardaram num banco no Brasil e foram achadas agora” -essa beleza é coisa para se olhar e para depois escolher. Aliás, assegura ela, beleza é muito diversa de artesanato, e Felipa confessa precisar tanto da beleza quanto “de ar” (35).

O MODELO MEDIEVAL

Mas, em contraposição à atualidade lingüística e literária demonstrada por Felipa escritora, o modelo feminino que subjaz a estes manuscritos pertence, todavia, a outras eras. Felipa confessa, lá pelas tantas, que permaneceria de bom grado na Idade Média, "teocêntrica e glutona, monja e cortesana”, se não fosse por certas "agruras” que eram próprias daquele tempo: “urinóis”, "privadas secas”, "banho de bacia”, etc (46-7).

Já se vê que, mesmo com humor, o teocentrismo é, de fato, o eixo que regula o universo de Filipa, e que pendores de se isolar e de se encarcerar num mosteiro são tentação antiga; por outro lado, ela bem sabe, como mulher, que "eremitério" lembra "cemitério" (34)... De resto, tudo para Felipa se resume numa "questão de fé” (50), o que faz dela, muitas vezes -e ela se auto-ironiza- uma "beata patética” (124).

Propensa a jejuns, holocaustos, sacrifícios, privações, penitências, novenas e promessas, sempre em constante reza com Deus - Felipa é uma mulher muito atormentada. E o que mais faz espécie nessa sua constituição sobressaltada é o sentimento de culpa, imanente a tudo o que lhe diz respeito, pois que se sente em permanente pecado ou nutre um constante sentimento de tentação provocado pelo demônio. E é por tais razões que ela se concebe estar, de fato, escrevendo um "livro de Jó” (90), patriarca da resignação bíblica que, aliás, “aprendeu a duríssimo preço, mas arou o seu terreno” (109).

No seu natural, a especialização de Felipa é a de pagar tributos por existir. Claro que ela não chega ao paroxismo de Clarinda, que se sente culpada e responsável até "pela seca do Nordeste” (108). Mas, a bem da verdade, Felipa tem medo, inclusive, de se vangloriar dos seus pecados, o que seria "uma forma equivocada e sórdida de aceitação da minha história” (107).

Mas se há algum erro, a culpa é sua -os "pecados estão vindo à tona, furando as sobrepelizes, boiando ao sol, não dá mais para enganar” (95). Se Martina morre, Felipa 
se sente culpada e tomada de remorsos por não tê-la assistido devidamente, de modo que chega a se perguntar a quem deve pedir "perdão por ter medido o meu amor”, a quem deve pedir “o perdão que necessito como de ar”, e onde está, “meu Deus, o lugar da expiação para que eu me cure?” (98). Se, por acaso, a saúde lhe volta, se sente culpada pelo Senhor tê-la devolvido (36), de maneira que, muito embora seus exames tenham dado ótimo, "a tristeza não sai, só quero chorar, chorar” (94).

Esses sintomas, que ela denomina com discernimento sua “herança mórbida”, são tão eficazes, que não lhe fornecem jamais paz. Assim, mesmo quando presencia uma inesperada revoada de pássaros, atestado da beleza e da felicidade, o que lhe dá o maior prazer - imediatamente sua culpa a faz supor que aquilo representa algum “aviso” (50). Felipa desenvolve, ao mesmo tempo, uma espécie de auto-perversidade que chega a transparecer em alguns dos seus atos, como se se punisse, como se se mortificasse. Lembro o caso dos anéis que, em vista dos seus aspectos dúbios, podem parecer cilícios: um, que ela não tira do dedo e que mergulhou na água sanitária para ficar preto; outro, que vai mandar fazer, de prata, quadrado e pesado, “com um sinal de martelo” (112).

Uma vez caída “em tentação”, Felipa sempre acha que peca quando escreve (46), de maneira que o seu desassossego é constante, pois que chega a ter medo de escrever e de "ficar feliz". "Por isso estou cheia de dores e tão feia?” (47) -pergunta ela. Nessas contradições um tanto masoquistas, imagina, ao mesmo tempo, que só poderá encontrar o perdão se escrever muito: "Pois é, meu Deus, pois é, meu Senhor, meu Pai Santo, quem sabe se eu escrever sem parar, dia e noite, como um capinador capina sua roça, vou ficar feliz de arrebentar” (135).

Nessa angústia incessante, Felipa convive tanto com Deus quanto com o demônio. Este agente da tentação é chamado por ela de "travesti nojento", "filho de uma puta, inimigo de Deus”, “seu bosta”, "rei do ardil”, aquele que se fantasia de medo (12). O demônio representa, para ela, todo o mal que a invade, encarnando, sobretudo, o medo, muito embora ele apenas denomine as suas próprias fraquezas, seus defeitos, suas tristezas e decepções. Mas, do modo como Felipa o concebe, o diabo parece ser uma entidade que vive fora dela mas que pretende, digamos assim, possuí-la: ele a ronda, “com desassossegado apetite” (como é o caso do “demônio da tristeza”) “ronda à minha cata, à cata do mundo, certamente aliciando mulheres como eu, nos confundindo quanto a hormônios, palpites na criação dos netos, minando com maestria os muros do castelo” (83-4). Ele “às vezes se descuida, porque é vaidoso, rabo e chifres aparecem. Aproveita tudo, o maldito, pra me tirar do sério” (84).

Enfim, Felipa vive em eterno litígio contra "Satanás”, contra o "Príncipe da Soberba”, que a experimenta, que procura enredá-la e seduzi-la, repleto de ardis: “o diabo peleja contra mim, sua armadilha é a compaixão negra, a tristeza sem esperança, a comida envenenada que me serve como um amante irresistível, quer me impedir de chorar e receber perdão, acena para mim com um choro melhor e mais perfeito que o choro dos meus irmãos” (67). A sua convicção é a de somos tentados sem descanso e que são os anjos aqueles que nos protegem contra "o avanço das trevas” (133).

Mas este império exercido sobre a sua alma não é apenas privilégio do demônio. Também Deus a submete a igual poder: "O Senhor, aquele que não me deixa em paz, sugere holocaustos novos, incruentas ofertas, ainda que inclua o corpo”(137). Segundo 
Felipa, Deus (assim como Satanás) também amedronta -e quem duvidar que pergunte a Jó, Jacó e Jonas, por exemplo, também a Jesus e “aos judeus apavorados suplicando a Moisés que não deixasse Javé descer da montanha” (142). Aliás, argumenta ela, a misericórdia de Deus se estende justamente sobre aqueles que o temem, de maneira que sua misericórdia é conhecida antes por sua cólera. Assim, “Deus precisa dos atormentados para manifestar sua glória” (125). ${ }^{6}$

Acerca dessas convicções de Felipa, Alba, sua maior e mais constante amiga, tem um parecer muito crítico: que o medo de Felipa decorre de um “catecismo errado”, o que a impede de ingressar no Novo Testamento (143). A própria dialética interna da novela se encarrega, pois, de explicar por esta via o clima apocalíptico que circunda a narradorapersonagem. Diante disto, não é difícil de sugerir que o protótipo feminino que Felipa encarna seja o da "possuída": seu corpo e espírito são lugar de vacância à espera de serem preenchidos. ${ }^{7}$ Candidatam-se a tal posse, tanto a entidade divina quanto a demoníaca que, dentro dela, se degladiam.

Na guerra surda desta narrativa entre essas duas potências, é o espírito de Deus que sai vitorioso na possessão de Felipa, esse, que é "patrão exigente”, do qual ela é apenas o instrumento, o "trabalhador alugado”. Felipa se põe a serviço de Deus como seu profeta, seu anunciador, pois que "se Deus precisar me dá mais idéias e eu escrevo outro livro. De onde tirei este tem mais” (160). E eis, aqui, o flagrante desse ato divino de posse:

Penetrai-me, ó Espírito Santo, agudíssima língua, endireitai minha espinha, levantai meu queixo, falai-me com uma tal voz que mais tenha dela certeza que de minha própria pele: Felipa, você é uma artista, sua roça é aqui, pega seu caderno, seu lápis de boa ponta e

\footnotetext{
${ }^{6}$ Vale a pena, neste passo, introduzir um episódio muito curioso narrado por Felipa no capítulo V. Ela ajeita, na travessa, umas romãs, e diz à Ivaneide que pode escolher algumas; esta, por sua vez, toma as maiores, as mais rosadas e bonitas, o que transtorna Felipa, pois que tais coisas "são quase como cortar um pedacinho do meu dedo mindinho. É muito difícil dar o mais bonito.” Mas Felipa melhora da "sensação de estar usurpada das romãs" quando as oferece "a Deus em holocausto. Foi como reavê-las. Fantástico!” (22). Por algum viés difícil de perscrutar, há um parentesco entre esta cena e a restituição de Perséfona dos Infernos. Zeus havia prometido a Cibele que recuperaria Perséfona, subtraindo-a do poder de Hades, se ela tivesse permanecido em jejum nos Infernos. Todavia Ascaláfio denuncia tê-la visto comer sete bagos de romã, o que demove Zeus. Ora, o fato de ter-se alimentado nos Infernos demonstra a fixação de Perséfona a essa região, fornecendo a ela um documento de naturalização indiscutível, já que comer dali (por muito pouco que fosse) significa compactuar com as leis locais. No caso de Felipa, o fato de ter ofertado em holocausto a Deus as romãs usurpadas (maneira de reavê-las), indica que pretende comer com Deus e não com Ivaneide que, neste caso, foi tentada a tomar as melhores. Todavia, esta interpretação resulta falsa, porque o ardil mágico para recuperar as romãs (já que Felipa é incapaz de se conformar de ter sido "usurpada”, acusação, aliás, injusta, imputada à Ivaneide, visto que a narradora ofereceu-lhe as romãs) -parece situar Felipa (em vista da própria incapacidade em doar aquilo que é mais bonito), como Perséfona, sob o poder de... Hades.

${ }^{7}$ Aliás, o estatuto de possuída preenche o aforismo lacaniano de que "A mulher não existe". Para Jacques-Alain Miller (De mujeres y semblantes) tal fato "não significa que o lugar da mulher não exista, senão que esse lugar permanece essencialmente vazio. E o fato de que esse lugar fique vazio, não impede que se possa encontrar algo ali. Nesse lugar se encontram somente máscaras; máscaras que são máscaras de nada, suficientes para justificar a conexão entre mulheres e semblantes” (84).
} 
capina sem preguiça, Felipa, de sol a sol, conta o que te conto. Serei feliz porque estarei liberta, mais ainda porque a roça não é minha, sou trabalhador alugado para patrão exigente, ‘que colhe onde não plantou', ai de mim, os Evangelhos dão calafrios. (135-6)

Não falta realmente nada para a configuração do seu estatuto de possuída: a penetração do Espírito Santo, ao mesmo tempo em que a torna arauto d’Ele, a liberta de si mesma, a salva. O clima de calafrio que a rodeia, próprio do Velho Testamento, indicia o teor desta temível potestade.

Os GRITOS ABAFADOS

Num rompante de sincera simplicidade, Felipa esclarece, logo no quarto capítulo, que escreve

estes Manuscritos do Curral, assim chamados porque o primeiro título, melhorzinho, $A$ casa que mora, me pareceu pedante -é pedante- e pedantismo é luxo para franceses, ultimamente em baixa, eles. O texto que se escreve para ocultar um subtexto que só os muito inteligentes vão sacar, faça-me o favor. Só há subtexto em textos diretíssimos como -vou arriscar- os loguia de Jesus: 'Ama teu próximo como a ti mesmo'. Mais direto impossível, mas vai viver o mandamento, experimenta e adentrarás à cidade submersa plantada em teu peito. (20)

O que Felipa declara aqui, a respeito dos “loguia” de Jesus, é o que se pode dizer da função dos seus sonhos nestes manuscritos, pois que, através deles, o seu leitor pode ter acesso às submersas ilhas erráticas que habitam o peito da narradora, perfazendo seu coração continental que, durante a narrativa dos fatos ocorridos em vigília, se encontra absolutamente fragmentado. Digamos, pois, que a teia significativa da voz desperta começa a se estender e a mostrar seus pontos e sua renda a partir da compreensão do que tais sonhos representam para o cariz feminino dessa quarentena.

Quanto mais não seja, para Felipa, é Deus quem lhe fala nos sonhos (132) e estes indicam que "o que se sente adianta-se ao que se sabe": afinal, os "afetos dos sonhos nos ensinam”. De resto, a felicidade "não é palavra humana, só em sonhos a suportamos” (158).

Assim, o primeiro sonho desta "iluminista ridícula”, que só teve inconsciente "depois dos quarenta anos” (45) é o do naufrágio (localizado no capítulo VII). Resulta, aparentemente, do clima de felicidade que envolve Felipa antes de se deitar, quando sequer tem necessidade de tomar a pílula para dormir, pois que passou o tempo brincando e se divertindo com o neto pequeno. Mas o sonho é aflitivo e muito diverso da temperatura serena que o antecede e o precede, pois que, uma vez acordada, Felipa tem a sensação de que se encontra de novo no seu eixo, e que não estranha mais o mundo em que vive.

Eis o sonho: à beira perigosa de um mar, Felipa deve salvar muitas crianças, inclusive algumas recém-nascidas. Duas pessoas a auxiliam, talvez a filha mais nova e, certamente, a mais velha, que chega depois. Um helicóptero tenta resgatá-las, e o piloto está nu: “onde lhe nascia o pênis e à volta do ânus a pele grotescamente espessa, enrugada e vermelha, parecia um porco, ele todo, um porco branco" (29). Ela chama a isso que vê de 
“animalidade dos humanos”; há também uma outra pessoa nua (que, para ela, parece ser uma mulher: uma “alemoa bondosa”) que, ajudando-os corria o risco de ser levada pela correnteza; Felipa grita a ela para que se agarre “a paus”, que se cuide, de maneira que, assim que esta consegue se salvar, abraça Felipa com carinho, apertando sua cabeça molhada (cabelos loiros grudados) contra seu peito. As crianças e todos se salvam, e as roupas sujas dos bebês, uma vez nas mãos de Felipa, não lhe causam nojo; por último, há uma perseguição de carros com tiroteio num canal do braço de mar que funciona como uma estrada.

O segundo sonho, o da menina-estuprada (localizado no capítulo IX), parece ser, logo em seguida, compreendido por Felipa, como se verá. Uma garota de nove a doze anos está sendo transportada por seu pai num carrinho de mão, tendo as pernas amarradas na altura dos joelhos ou dos tornozelos; ela havia sido estuprada por um moço que ainda abotoava as calças, moço que a encontrara num quartinho onde ela adormecera, já que a menina acompanhava o pai aos locais do trabalho dele, desde que lhe morrera a "mãe triste e esquisita” (38). Felipa pensa que a menina consentira e que não pudera ter suficientes forças para afugentar as "sucessivas ondas do embriagante calor que as mãos e a lança em riste do moço provocavam” (37). Ela está sendo transportada pelo pai, nesse carrinho, cujos solavancos lhe são penosos, e tem os olhos e a boca entreabertos, chocada, olhando para o nada; o pai, que raciocina, sofre mais à medida que compreende a situação, tomado de compaixão também pelo estuprador -e é por isso que não o mata. A certeza de Felipa é a de que foi o pai quem amarrou, depois, as pernas da filha.

O efeito que tal sonho desperta em Felipa decorre do lapso lingüístico que ela comete, o que a faz supor que Deus é o pai, de maneira que tudo o que Lhe pede é que a trate com a mesma ternura com que o pai da menina a tratou. $\mathrm{O}$ enigma das pernas amarradas, entretanto, persevera, e Felipa pergunta-Lhe: “Sois Vós o pai? Começas a amar-me? Mas por que as pernas amarradas? Agora vejo e não ando?” (39)

O terceiro sonho, cuja interpretação - muito simples para Felipa - a leva a tomar todas as medidas contra a sua "teimosa procrastinação", é o do apelo-não-atendido. Sua amiga Alba, suas duas irmãs e sua mãe já idosa, vêm muito cedo lhe fazerem uma visita, de maneira que Felipa se sente envergonhada por se encontrar ainda em plena preguiça. Quer recebê-las muito bem, lhes oferecer algo, e as convida para que entrem em sua casa; todavia, para ali penetrarem, devem atravessar "cômodos emendados”, um deles sendo um “salão de beleza atapetado de cabelos” (111), e a incomoda que pisem naquilo levando a sujeira para dentro da casa. Portanto, sugere que dêem uma volta, o que as endereça a um caminho que termina num muro e num córrego. Felipa e a mãe de Alba escalam o muro (Felipa se admirando da agilidade da velha), mas o córrego vai engrossando (há mesmo um grupo de homens que vêm trazendo uma esteira flutuante para salvá-las), e Felipa grita, debalde, em vão, por Teodoro, que ela sabe estar dentro de casa (seu marido que, mesmo em sonhos, jamais lhe negou ajuda); em seu lugar, depois de vários apelos, aparece Breno (muito provavelmente seu filho).

O quarto sonho é o do casamento -que ocorre no capítulo XXXIII, o que demonstra uma prolongada pausa entre o anterior e este), e Felipa logo o interpreta através do "medo" que impera sobre ela, na medida em que repara que "noivo" remete a "goivo, a flor funérea”, muito embora aquilo que ela gostaria de dizer a quem a desejasse esposar fosse: 
“trate-me com doçura” (132). As lembranças que guarda deste sonho são as de que trabalha duramente na grande casa para preparar o seu casamento que, aliás, ela deseja muito; mas há muita coisa para fazer ainda e Felipa está aflita diante da alheação absoluta da sua mãe, do seu pai, de Teodoro (que é outro mas que é ele, seu marido), de sua filha (provavelmente com seus filhos), dos sobrinhos e de um grupinho alegre que conversa. Ela quer a casa bonita e, portanto, a varre, limpa os armários, fica desgostosa com o pó de caruncho, a louça ainda suja; quer muitas flores por todos os lados e bombons à mão das pessoas. Ela reclama, aos gritos, que quer ajuda, que é o seu casamento-e todos continuam impassíveis, inclusive a mãe, de quem fica com raiva. Pede, sem graça, dinheiro a Teodoro para comprar bombons, porque ela quer muitos e não tem o suficiente, e alguém se oferece para ir buscálos: mas essa pessoa é "um meio bobo" (132) e compra errado, trazendo, em lugar dos bombons, uns biscoitos pobres, desses cobertos de chocolate. Ninguém de fato a ajuda: algumas mulheres lavam com mangueiras a frente da casa, mas é só mera desculpa para conversarem entre si: esta é a segunda vez que Teodoro não a socorre em sonhos.

Sobre o quinto sonho (o do "leite”), o sexto (o dos “adoradores”) e o sétimo (o das "duas-mulheres vestidas de modo igual dentro de um lugar que parecia um grande túmulo”), todos “sonhos de salvação”, segundo Felipa -não há registros, a não ser um comentário de que o das duas mulheres é o "mais estranho deles” (149). São sonhos noticiados no capítulo XXXVIII, e teme-se, então, que não haja espaço para que sejam registrados: "precisarei escrever além de quarenta textos. Queria fossem apenas quarenta os destes manuscritos, porque é um número redondo e significante, bobagem, não se premeditam essas coisas, vou escrever o necessário, esta, a regra de ouro” (149).

O oitavo sonho é o da velha-criança, e ele é anotado imediatamente após os anteriores, já no penúltimo capítulo do livro. Eis seu relato: no colo de uma mulher (Arlete de Zé Lúcio, aparentemente sua cunhada) está uma criança magra, com as costas cobertas por uma varicela miudinha que esconde a pele; a cara do nenê é a de uma velha (que pode ser a de Felipa), com o cabelo dela: ela não sabe se é uma velha-criança ou se uma criançavelha. Em seguida, Felipa se encontra voando sem esforço por uma alameda de altas árvores, conduzida deliciosamente pelo vento que a refresca e, assim, ela entra (ou cai) numa construção retangular semelhante a um túmulo de concreto abaixo da superfície; lá dentro, sentada, está uma freira velha vestida de branco, com o véu azul celeste e, mais ao fundo, num nível superior, está Nossa Senhora vestida exatamente igual. A freira está imóvel, como se aguardasse há séculos para se mover, e, finalmente se move; o lugar é limpo, não mete medo, é apenas estranho, e Felipa canta "Ó Maria, ó Mãe cheia de graça" à Nossa Senhora (primeiro com a voz falha que, depois, se torna límpida), e vê, ao alto, a abertura por onde pode sair, que filtra uma claridade, mostrando o dia - o que fica lá para fora (154). Depois, um frei seu conhecido (Canísio) vai ser sagrado príncipe cardeal e parece que há ainda outros frades. O fato é que Felipa confessa não ter entendido bem este sonho, salvo as duas primeiras partes que, aliás, já foram sonhadas outras vezes. Porém, ela não explica como as interpretou.

O nono e último sonho consiste no derradeiro capítulo desses Manuscritos, e vai auxiliar sobremaneira Felipa a encerrar o ciclo da sua quarentena por dentro do medo, concretizando a saída dessa provação. Trata-se do sonho da amamentação: Felipa segura em seus braços, com prazer, o filho de Rebeca (sua filha?), criança miudinha mas saudável, 
que começa a chorar de fome. Ela lhe oferece o seio, que a criança mama sofregamente; a sensação lhe é extremamente gozoza, o que a faz pensar que "por isto dispenso orgasmos” (157). Felipa passa o menino para o outro seio, e ele continua a mamar até regurgitar, e, durante todo o tempo, perdura o gozo de Felipa. Conversando com as pessoas, ela mostra a criança, de quem era avó e não mãe, fato conhecido de todos.

A interpretação que Felipa tece a respeito deste sonho a faz considerar que a essência dele pode ser dita “A glória do corpo”. Segundo ela, “a natureza da criança era a de um homúnculo, dava-lhe de comer exatamente para que não crescesse e não crescendo não se corrompesse, alimentava a criança divina” (157-8).

O DEVANEIO SECRETO

Longe de tentar uma interpretação psicanalítica ${ }^{8}$ deste elenco de sonhos que funciona, portanto, como uma espécie de enredo submerso e latente da narrativa, interferindo subrepticiamente nela, ampliando-a e minuciando as questões por ela colocadas ou insinuadas, ora posicionando-as na sua mesma vala, ora desnivelando-as e camuflando-as -pretendo observar apenas o que esses apelos do inconsciente da narradora-personagem provocam quando inter-relacionados. Quem sabe, assim, será possível conhecer uma espécie de sintaxe dos gritos dessa voz feminina que o medo busca sufocar.

Em todos os nove sonhos, com exceção do sexto, cujo conteúdo é ignorado, visto que a menção a ele feita (a de que se trata dos “adoradores”) é insuficiente, a mulher - seja em suas diferentes faixas etárias (como criança, adolescente, de idade madura, idosa, velha); seja em suas funções familiares (de mãe, esposa, avó, tia, nora ou cunhada, enfim, de dona do lar); seja em seus constituintes físicos e espirituais (como mulher-objeto-de-desejo, como usufruidora-do-prazer; como mulher-monja, como mulher-santa, como Virgem Maria) -está fortemente presente. Essas várias investiduras do feminino contemplam até mesmo a mulher de sexo suspeito (o que pode ser o caso da "alemoa bondosa" do primeiro sonho, que, para Felipa, parece mulher, 29), mas não a cortesã, contrariando, aliás, aquela afirmação da narradora acerca dos papéis femininos que a atraem na era Medieval: de “monja” e "cortesana” (46). ${ }^{9}$

\footnotetext{
${ }^{8}$ Felipa assume diretamente sua má-vontade para com interpretações deste tipo, ridicularizando-as e caricaturizando-as, quando comenta que a "psicologia é nova, mas já tem suas múmias: ‘é pena a senhora fazer seu dedo de pênis’, só porque me queixei que me doía a cabeça do dedo, era problema de unha que crescia pra baixo. Imagina se deixo médico desse tipo tocar na minha tristeza!” (151). Apenas o espírito que instruiu Daniel teria, como confessa, suficiência para auxiliá-la na decodificação desses sonhos.

${ }^{9}$ Sempre que analisar os sonhos, o sexto, em virtude da mais pronunciada carência de informações, fica descartado; quanto aos do "leite” e das “mulheres-iguais”, estes são tomados apenas rasteiramente naquilo que a semântica do seu título permite concluir, ou seja: "leite” remete à maternidade; "mulheres-vestidas-iguais" remete à semelhança, à temática do geminado, da "filipa", que desenvolverei em seguida. Daqui por diante, sempre que me referir a "todos" os sonhos, estou contando apenas com seis deles, visto que excluo o quinto, o sexto e o sétimo, pelas razões que acabo de apontar.
} 
A maternidade é preponderante nessas situações oníricas, em que o agente do sonho ${ }^{10}$ ou é mãe (a do naufrágio, a do apelo-não-atendido, a da velha-criança, a da amamentação, presumivelmente a do leite) ou participa das ações enquanto ausência pronunciada, como é o caso da “mãe triste e esquisita” (38) do sonho da menina- estuprada, cujo desaparecimento determina os acontecimentos que culminam com a violentação da menina; ou como ocorre no sonho do casamento, visto que a indiferença da mãe de Felipa diante dos seus apelos faz com que esta se ressinta dela, nutrindo raiva pelo comportamento maternal. Ou, ainda, enquanto função duplicada no mesmo sonho, como é o caso do sonho do apelo-nãoatendido, em que a figura materna comparece no agente e (digamos) numa personagem secundária -a mãe de Alba, uma senhora idosa, que se mostra mais ágil que suas filhas; como é o caso do sonho do casamento, em que a filha de Felipa está, provavelmente, com seus filhos; como no caso do amamentação, em que Felipa é avó e mãe. ${ }^{11}$

A situação revelada pelos sonhos é sempre de âmbito familiar, mesmo no caso da menina-estuprada, pois que, então, os papéis familiares são fortalecidos na figura do pai que, além de desempenhar-se como chefe de família, de responsável pela integridade física e moral da filha, ainda substitui a função da mãe como ama da menina, como pajem da menina, desempenho maternal que se choca com o papel paternal de provedor do lar -o que vai explicar, na lógica do sonho, o abuso sofrido pela garota. Ou seja: a desordem familiar (a falta da “casa”) responde pela violentação. Aliás, o que também justifica, antes da intercessão masculina, o salvamento das crianças no sonho de naufrágio é a organização familiar: não esquecer que ao lado de Felipa estão duas pessoas que a auxiliam: a sua filha mais nova e, em seguida, a sua filha mais velha. Também, no sonho do casamento, o que ocasiona agonia e aflição em Felipa é justamente a organização familiar completamente indiferente a seus rogos.

A “casa” (o “lar”) é, portanto, um valor pronunciado nesses sonhos, cuja ausência provoca uma falta grave, séria e conseqüente, como no caso da menina-estuprada. A casa também comparece como lugar de privacidade, desempenhando-se enquanto espaço de difícil acesso a ser alcançado (no caso do apelo-não-atendido quando, então, a visita à intimidade pessoal não pode ser concretizada), ou de difícil conservação (no caso do casamento, quando a intimidade se encontra em reboliço, alvoroçada) ou, ainda, enquanto espaço tumular de reclusão que, contém, todavia, uma abertura para o fora (no caso da velha-criança).

Há, assim, no transcurso onírico, uma gradação na representação da intimidade: o mundo privado parece ir-se fechando para alcançar, contraditoriamente, a sua alforria. Porque não podem passar desapercebidas as imagens tão significativas da freira imobilizada há séculos, que se move, por fim; a do canto de Felipa, que irrompe pouco a pouco de sua boca, ganhando limpidez, para louvar Nossa Senhora; e o vislumbre da fresta ao alto, por

\footnotetext{
${ }^{10}$ Estou considerando como "agente do sonho” não à Felipa, a que sonha (a quem é mais apropriada a expressão de "produtora do sonho”), mas àquela que desempenha o papel principal na situação onírica. No caso, por exemplo, do naufrágio, do apelo-não-atendido e da amamentação, Felipa é também o agente; todavia, no caso da velha-criança, ela é a criança que se encontra nos braços da mãe, a Arlete de Zé Lúcio, sendo esta quem detém o papel de agente.

${ }^{11}$ Já aqui aparecerem indícios da tópica do geminado.
} 
onde se pode sair do mausoléu e por onde se nota a luz do mundo exterior. E é bom lembrar que este é o penúltimo dos nove sonhos de Felipa, encontrando-se na antesala do término da quarentena -um dos derradeiros passos para a resolução da “doença” e de desembocamento na "cura".

Os sonhos podem ser considerados não como sonhos de "salvação", como o quer Felipa para aqueles que não narra (149), mas mais propriamente "sonhos de salvamento". Nos casos da menina-estuprada, do apelo-não-atendido e do casamento, pode-se dizer que o salvamento é desviado e concretizado, digamos assim, por interposta pessoa. No primeiro, ele é reparado, visto que o pai amarra as pernas da filha a posteriori (o que também pode ser visto como uma castração, o que, aliás, ilumina a imobilização ancestral da freira do oitavo sonho); no segundo, embora o marido não atenda Felipa, quem responde ao seu apelo é o filho; no terceiro, embora não sejam os bombons almejados os que chegam à Felipa, lhe são trazidas, ao menos, as bolachas cobertas de chocolate. Ou seja: os fins não são alcançados da maneira como são pretendidos, mas são, digamos assim, remediados.

Este não é, em absoluto, o caso dos restantes sonhos: no do naufrágio, o salvamento é completo (muito embora o anexo final do tiroteio-de-carro empane um tanto esse sucesso). O da velha-criança também se coroa de sucesso, visto que a nesga de abertura indica a saída de um possível impasse que impediria o salvamento; e o da amamentação é todo ele um êxito total. Primeiro, porque desenha uma ilação com o primeiro dos sonhos, fechando um ciclo e redimensionando-o: as crianças pelas quais Felipa luta no naufrágio do primeiro sonho, estão salvas na criança que Felipa amamenta agora, visto que estão alimentadas e, portanto, já não correm risco de vida. Esta criança do derradeiro sonho é, portanto, redimida da fome pelo leite materno, ao mesmo tempo que a avó-mãe descobre a glória do seu corpo (orgasmo, gozo, felicidade) salvando a criança -e salvando-se como mulher. Além disso, a interpretação que Felipa fornece a este sonho a leva a ultrapassar definitivamente o medo da morte e do envelhecimento, e confirma a saída da quarentena e sua "cura”. É, pois, neste sentido, que estes últimos sonhos podem, sim, ser ditos puros sonhos de "salvação" -de "redenção".

Chamo a atenção para o fato de que é, exercendo os dons femininos do seu sexo, ou seja, as prerrogativas próprias da sua libido -que Felipa deixa a quarentena e é salva. Mas é deveras bizarro que seja antes com o seu corpo “de mãe” e não com o seu corpo “de amante” que Felipa procure, ainda que inconscientemente, uma resolução, visto que o "orgasmo" obtido com o companheiro pode ser preterido -pode ser, como se diz ali, dispensado em favor do gozo conseguido pela amamentação: "Mamou sofregamente, eu sentia formar-se o leite abundante, era gozoso e pensei: por isto dispenso orgasmos” (157). Aliás, as crianças -“oráculos a quem devemos ouvir, servir com incansável amor” (155)estão presentes em todos os sonhos, como uma espécie de motivo obcecante que, sem dúvida, entra em comunicação com a sua outra face, a velhice -tópica fundamental do livro.

Mas é bom lembrar que, no caso deste derradeiro sonho, Felipa alimenta, como ela própria conclui, a “criança divina”, devaneio que a eleva à condição de mãe de Jesus, de Virgem Maria-fantasia que se enraiza de maneira mais vincada na narrativa, como se verá, e cujos corolários serão decisivos para o entendimento desses Manuscritos. 
Outra constante em todos os sonhos é a noção do sujo-e-limpo que, quando tornada preocupação, é sempre emitida do ponto de vista feminino. No naufrágio, por exemplo, a roupa "suja" das crianças não faz nojo à Felipa, certamente porque foi purificada pela água do mar em que as crianças soçobraram; no estupro-da-menina vagueia certamente uma noção contrária a esta, a de abuso, de corrupção de menor, portanto, daquilo que é oposto ao "limpo"; no apelo-não-atendido, é a determinação de não levar "sujeira” para o interior da casa ("sujeira”, aliás, cuja natureza é digna de exame, pois que se trata de cabelos femininos existentes no chão do salão-de-beleza), que obriga Felipa a um decurso que culmina na decepção com Teodoro; no sonho de casamento, a presença dessa semântica faz espécie, pois que pontua o incômodo de Felipa -a louça está ainda "suja”, ela varre a casa, ela "limpa” os armários, contrariada com o "o pó de caruncho” (131)- e um grupo de mulheres tagarelas "lava”, com "mangueiras”, a frente da casa. No sonho da velha-criança, a "varicela miudinha" que cobre por inteiro as costas da criança (em que a própria Felipa se reconhece) pode ser apreciada como índice de "sujeira” que, todavia, no transcorrer do sonho, vai encontrar seu complemento na "limpeza" existente dentro do túmulo, que comparece por duas vezes - “uma construção retangular, grande e limpa” (153) e "Tudo era limpo e não metia medo, era só estranho" (154). Desta feita, reiterada, chama a atenção o fato de que a "limpeza" esteja associada à "ausência de medo".

No último sonho, o sonho redentor, não há nenhuma menção explícita de uma ou de outra qualidade, mas o leite que alimenta a criança é branco e toda a atmosfera de felicidade, gozo e bem-estar onírico condiz com a semântica da "limpeza”, que pode ser ampliada para a de "legitimação", pois que Felipa está concretizando um ato apoiado e sancionado por todos, visto que conversando "com as pessoas, mostrava a criança, sabia que era a avó e não a mãe, mas era formidável que outros também soubessem” (157).

Por tais ínvios caminhos é possível afirmar que, no transcorrer desses sonhos, a dicotomia inicial sujo-e-limpo vai, gradativamente, esclarecendo seu sentido polar de, respectivamente, medo e ausência-de-medo, de indecência e decência- de ilegítimo e legítimo.

Outro dado significativo é que, nos primeiros quatro sonhos, o papel feminino seja preponderantemente de vítima, o que permite dar relevo à salvação e ao desempenho do papel masculino. O homem, aliás, participa de todos os sonhos (digamos) "profanos" como também do único sonho declaradamente “religioso”. De uma maneira geral, está em suas mãos a redenção final da mulher. É o piloto do helicóptero quem acode, por último, as crianças e as mulheres (sonho do naufrágio); é o pai da menina que a defende (embora depois de perpetrado o estupro) amarrando-lhe as pernas, e é ele quem procede como um juiz absolutamente isento, visto que sua compreensão do caso, ainda que patética, não lhe permite punir o violentador (sonho da menina-estuprada); as mulheres seriam retiradas do córrego por uns "homens como um grupo de salvamento" (112) se não lhes acudisse o filho Breno (sonho do apelo-não-atendido); é um "meio bobo" quem se oferece para comprar os bombons desejados por Felipa, enquanto o futuro-marido Teodoro detém o poder -o dinheiro (sonho do casamento); Felipa visita Nossa Senhora, canta para ela, mas é frei Canísio quem vai ser sagrado "príncipe cardeal” (154); Felipa amamenta a criança que, afinal, é "um homúnculo, dava-lhe de comer exatamente para que não crescesse e não crescendo não se corrompesse” (157). 
Tal assertiva final acerca deste "homúnculo”, cujo crescimento significa corrupção, desenha um parentesco com a dicotomia sujo-e-limpo, e flexiona as razões pelas quais, ao longo do processo onírico de Felipa, a figura masculina vai se despindo dos seus traços sexuais peculiares. Observo que a "animalidade dos humanos", surpreendida no primeiro sonho, e que radiografa o homem nu do helicóptero salvador -“onde lhe nascia o pênis e à volta do ânus a pele grotescamente espessa, enrugada e vermelha, parecia um porco, ele todo, um porco branco" (29)- será substituída, pouco a pouco, por um enfraquecimento gradual dessa "animalidade” (que, aliás, é muito bizarra, porque vem do "alto”, vem do "céu”) em troca do fortalecimento dos traços sexuais femininos.

Assim, resquícios deste tipo de masculinidade habitarão ainda, no segundo sonho, a figura do estuprador -e refere-se ali ao "embriagante calor que as mãos e a lança em riste do moço provocavam” (37) ${ }^{12}$-, que se contrapõe à imagem do pai dessexualizado e justo que, por sua vez, será substituída (no terceiro sonho) pela de um marido que falha e que, portanto, cede seu lugar ao filho. ${ }^{13}$

Nessa cadeia de subtração da masculidade, este filho do terceiro sonho oferece seu posto ao sujeito "meio bobo" do quarto sonho (que faz oposição -e ao mesmo tempo se iguala- ao poder do marido que, novamente, falha) e que, por sua vez, cede seu espaço, no sonho seguinte (o oitavo) à figura do frade que, por sua vez, no sonho derradeiro, se desloca para a figura do "homúnculo" -este, sim, do “céu”!

Assim, enquanto o homem vai perdendo a sua marca sexual, espiritualizando-se, a mulher, no decurso dos sonhos, vai ganhando em libido, de maneira que compõem os polos do percurso onírico, de um lado, a “animalidade” masculina (contida na inauguração do processo inconsciente) e, de outro, a “glória do corpo” feminino (contida na finalização dessa cadeia). É como se o corpo feminino absorvesse ou engulisse ou apagasse o corpo masculino -a sua virilidade.

De maneira que, muito embora o homem ocupe um papel proeminente como "salvador", ele sofre, de fato, no transcurso dos sonhos, uma crescente e paulatina descaracterização da sua masculinidade em proporção direta à crescente caracterização sexual feminina, cuja tônica não descansa sobre a mulher-amante, mas, bizarramente, sobre a função maternal da mulher. ${ }^{14}$

\footnotetext{
${ }^{12}$ Seria deveras necessário deter-se mais sobre a natureza desse estupro. Primeiro, porque há uma reincidência dessa situação também no discurso desperto: o estupro de que foi vítima Valdemildes, que ocorre, aliás, depois do sonho da menina-estuprada. E, segundo, porque, no sonho, o sexo-e esta é a única aparição explícita de uma relação sexual em todo o livro-, comparecendo como violência, perde, em seguida, tal carga negativa em virtude da “compreensão” paterna.

${ }^{13}$ Por algumas vezes, na narrativa desperta, Felipa refere a sua dificuldade em suportar qualquer indício de fraqueza da parte de Teodoro; lembro o episódio do telefonema (capítulo XVII) e o da manteiga na roupa (capítulo XIX), quando ela declara que tem necessidade "do veneno e do travo" de Teodoro (78). Já neste último caso, a fraqueza se alia à "sujeira”: quando Felipa surpreende a "mancha" da manteiga "a uma chave da braguilha” de Teodoro, "mancha ainda quase úmida" -ela, furiosa, lhe ordena: "Deixa eu lavar esta merda" (77).

${ }^{14}$ Seria necessário, agora, procurar compreender o funcionamento dos "neutrinos” (141), ou seja, entender também as transformações operadas na relação entre fatos oníricos e fatos de vigília (e viceversa), observando as interferências mútuas, para se especular sobre a maneira como estes estimulam
} 
A FILIPA

A incidência da paronomásia, nestes Manuscritos, como auxiliar na elucidação da semântica de algumas palavras, ${ }^{15}$ permite, já agora, uma aproximação entre "Felipa" e “filipa” -e, neste caso, fala-se de sementes que se apresentam grudadas uma às outras, o que nos endereça à tópica da geminação. Quando mais não seja, a forte presença da imagem da duplificação (que congrega também em si a de espelhamento), presente nesta narrativa, parece autorizar a interpretação de que esta Felipa seria emblemática da mulher temente a Deus.

A propósito, relembro, dentro da série onírica, a redundância de figuras maternais, o maciço comparecimento de crianças, a reincidência de sonhos em que as mulheres estão vestidas da mesma forma dentro de um túmulo (como é o caso do sétimo e do oitavo sonhos), a repetida reação da parte de Teodoro (sonhos do apelo-não-atendido e do casamento), o relato da casa com "cômodos emendados" (sonho do apelo-não-atendido).

Também se conhece a parecença de Felipa com sua irmã Marcela, e a narradora esclarece, em determinado momento da novela, que não vai falar de Marcela porque "falo de mim, que dá na mesma, somos como gêmeas, empacadas, tristes, pesadas” (34). Desse mesmo ponto de vista, ela e Alba são ambas do "sexo passado" (86) -de modo que Felipa também pode ser legitimada, no transcorrer de toda a narrativa, como emblemática da mulher idosa, visto que contém em si a panóplia simbólica da entrada na velhice. Aliás, a propósito desta situação, Felipa ostenta uma versão modelar:

Sabemos do que se trata: chegou o futuro. É aqui, nesta esplanada deserta, com três edificações escondidas como casamatas, uma igreja, uma empresa de turismo, uma clínica de repouso. Você sobe a um promontório onde a areia é mais firme e olha em volta o deserto. Não mudou nada em sua alma, contínua de infinitos desejos. (84)

No que concerne ao título desta obra, sabemos que Felipa pensou primeiro em “A casa que mora”, substituindo-o por "Manuscritos do Curral” (20), que, como se compreende no transcorrer da narrativa, foi trocado por "Manuscritos de Felipa". Ora, enquanto escreve estes Manuscritos, a narradora-personagem começa a engendrar um outro livro

a ocorrência daqueles e que efeito produzem os sonhos sobre as resoluções que a narrativa vai engendrando -estudo que não ambiciono encetar aqui. Para se ter idéia da importância dessa matéria, lembro que, após este último sonho, Felipa descobre que a morte é a travessia de um pontilhão no colo de Deus (posição invertida da “criança divina” que, no derradeiro sonho, estava no seu colo) - isso, inspirada na visão de Teodoro, que ajuda um menino a atravessar o pontilhão, colocando-o no colo (159-160).

15 Remeto aos casos de "noivo" e goivo”, de "eremitério” e “cemitério”, por exemplo. Lembro também que, curiosamente, o sobrenome de Felipa, aquele da linhagem da raça “redentorista”, é Marroio. Este significante (que denomina uma planta da fam ilia das labiadas) se comunica com “marraio” (palavra que, em certos jogos, permite, àquele que primeiro a gritar, jogar por último o que é um privilégio) e com “marroaz” ou "marruá” (novilho não domesticado, boi bravo, touro obstinado ou tinhoso), semântica que, de alguma forma, se coaduna com a teimosia ancestral de Felipa. Nesta última acepção aplaca-se a bizarria do projetado título de “Manuscritos do Curral” para este livro. 
que teria como título “Filandras”. E, a propósito deste último título, é indicial que, no capítulo concernente à descoberta dos neutrinos, quando a narradora fica rabiscando a dedicatória que fará para Teodoro, alguém declare -por Felipa e na terceira pessoa!-que

Esta, a dedicatória que Felipa escolheu para finalizar seu caderno, significando que tornava público seu amor por Teodoro e também a permissão para ele ler os textos. - Mas tem aqui uma confusão que percebo a tempo. A dedicatória que penso fazer não é para estes manuscritos e sim para Filandras, que ainda não escrevi. E o modo como expliquei a dedicatória é o de uma terceira pessoa, parece a fala de um estudioso em cima de um pergaminho. Eu falando de mim mesma, como se fosse outra?! Sai, capeta, te imiscuiste. (141-2)

Aqui há vários indícios a considerar. Além do significado dos títulos, ainda a tratar, chama a atenção a confusão (certamente proposital) entre primeira e "terceira pessoa", entre a dedicatória pensada para um livro que, em verdade, é outro. Ora, "Filandras” é, de fato, um livro que Adélia Prado escreveria posteriormente - mas não Felipa. ${ }^{16} \mathrm{E}$, se ocorre o que aqui se passou, ou seja, se "uma pessoa", de repente, surge na narrativa, rouba o discurso da narradora e toma Felipa como uma "outra”, pode-se inferir, com segurança, que se trata de uma autora falando da sua máscara ficcional, ou seja, de Adélia Prado dando conta de Felipa. Ora, tal índice nos introduz definitivamente no território das "filipas”.

Além disso, esta citação comprova como a presença do "capeta” designa, tal como já se disse, uma invasão no interior, na intimidade da "possuída”: sua atuação é sentida como algo que se "imiscui” na narrativa. Ora, é sempre tal interferência (a daquela que usa uma "terceira pessoa”), tal imiscuição "autoral” (que, afinal, subjaz ao fingimento ficcional) que transforma uma narrativa em... literatura. Donde agora se vislumbra uma atribuição mais simpática para o capeta: a de que ele permite ficcionar! Já o Espírito Santo, que faz de Felipa o seu arauto, o seu instrumento, o seu mensageiro -também a transmuta em Sua filipa.

Mas, de fato -como não poderia deixar de ser!- o espectro, a energia de um autor povoa sempre os seus escritos. Assim, para além de Felipa adotar as temáticas que são tão típicas de Adélia Prado, não é, em contrapartida, verossímil que aquela tenha, como declara no capítulo XXXVIII, penado "por ter falado demais" e perdido "tesouros enquanto os comunicava a ouvidos despreparados julgando ser generosa” (149), já que, dentro da simulação ficcional, estes Manuscritos parecem ser a inauguração de Felipa como “autora”, como narradora-personagem. Também não é verossímil, por isso mesmo, que Felipa tenha qualquer tipo de experiência com a crítica literária e que infira que "um crítico”, diante desse mesmo capítulo (que, segundo ela, está um pouco esquisito), ajuizaria estar ele “"um curral'” (152) -aliás, coincidindo com o mesmo tipo de título que seria, de início (e não sem um tom de ironia), atribuído ao livro. Também é inverossímil que Felipa declarasse que "fotografia de crítico causa medo, o crítico no seu apartamento, o crítico na sua biblioteca, em meia folha de jornal. Quero ver um crítico é em Aparecida, dá uma sede, uma fissura por café e sanduíche, ia mudar muita coisa, mas lá é lugar pra

${ }^{16}$ Adélia Prado publicaria tal obra em 2001, no Rio de Janeiro, pela Editora Record. 
jagunço e pecadores, por isso fui” (151). Ficcionalmente, é, pois, Adélia Prado quem se adere à Felipa, quem se torna filipa de Felipa, e não o inverso: a verdadeira autora comparece, assim, como a "outra” da narradora-personagem.

O fato é que, nesta novela de mulheres, em que, por caminhos insidiosos e subreptícios (talvez seja lícito dizer isso da via onírica...), a narradora-personagem, à medida que subtrai, dos homens, as suas marcas sexuais em proveito da maternidade que ela própria se oferece como amamentadora da criança divina -acabe por se endereçar (ainda que pelo avesso!) a uma questão fundamental a respeito do que almeja para si. Revelandose "criatura”, Felipa não entende "como não sou Deus, se Lhe sou a sombra perfeita em falta absoluta e carência. Descubro então meu poder, o de não ser nada nem ter. Contudo, sim, contudo, aqui tresmalho do próprio entendimento e me ponho como Nossa Senhora a visitar meus parentes ocultando a pérola no seio”(127).

Mas, nessa espécie de ascensão à santidade em que a narradora-personagem procura se construir, ${ }^{17} \mathrm{o}$ embate entre feminino e masculino permanece revolvendo-se em plena dubiedade.

Se, como Felipa conclui, sua mãe não é quem supõe, porque sua "vera mãe” é, ao contrário, “Deus” (Aquele que "só em Jesus prestou conta de seus atos”), visto que "uma mulher” não pode ser mãe, mas apenas “irmã” (109) -quem é que se erige, afinal (oniricamente ou não), como sendo a mãe de Deus?

\section{BiBLIOGRAFIA}

André, Serge. O que quer uma mulher? Rio de Janeiro: Jorge Zahar Editor, 1987.

Aubert, Jean-Marie. La femme. Antiféminisme et Christianisme. Paris: Cerf/Desclée, 1975.

Bataille, Georges. O erotismo. Lisboa: Moraes Editores, 1968.

Brando, Ruth Silviano. Mulher ao pé da letra. A personagem feminina na literatura. Belo Horizonte: Editora UFMG, 1993.

Chasseguet-Smirgel, Janine. Sexualidade feminina. Uma abordagem psicanalítica contemporânea. Porto Alegre: Artes Médicas, 1988.

Chevalier, Jean e Alain Gueerbrandt. Dictionnaire des symboles. 4a. ed. Paris: Seghers/ Jupiter, 1974. 70-71.

Didier, Béatrice. L'écriture-femme. Paris: PUF/Écriture, 1981.

Miller, Jacques-Alain. De mujeres y semblantes. Buenos Aires: Cuadernos del pasador, 1994.

Pommier, Gérard. A exceção feminina. Os impasses do gozo. 2ª ed. Rio de Janeiro: Jorge Zahar Editor, 1991.

Prado, Adélia. Manuscritos de Felipa. São Paulo: Siciliano, 1999.

Schneider, Monique. De l'éxorcisme à la psychanalyse. Le féminin expurgé. Paris: Retz, 1979.

\footnotetext{
${ }^{17}$ Felipa possui, de fato, um projeto de procura de santidade -à sua maneira. Tendo como lema a orientação de todos os santos - "'Sede perfeitos, como o Pai é perfeito”" (133) -, ela se dá conta de que não é possível "imitar um santo, devo construir-me, é esta a sua fala, por isso está nos altares" (133).
} 